\title{
Anti-progesterone monoclonal antibody affects early cleavage and implantation in the mouse by mechanisms that are influenced by genotype
}

\author{
V. Rider*, R. B. Heap, M.-Y. Wang $\dagger$ and A. Feinstein \\ AFRC Institute of Animal Physiology, Babraham, Cambridge CB2 4AT, U.K. and $†$ Shanghai \\ Institute of Planned Parenthood Research, 2200 Xie Tu Road, Shanghai, People's Republic of China
}

\begin{abstract}
Summary. Pregnancy was blocked by anti-progesterone monoclonal antibody in two inbred $(\mathrm{BALB} / \mathrm{cJ}, \mathrm{CBA} / \mathrm{Ca})$ but to a lesser degree in an $F_{1}$ hybrid $(\mathrm{CBA} / \mathrm{Ca}$ $\hat{0} \times \mathrm{BALB} / \mathrm{cJ}$ ) ) or an outbred (Tuck's no. 1) stock of mice when antibody was injected intraperitoneally (i.p.) at $32 \mathrm{~h}$ post coitum (p.c.) using a dosage of 9.5-10.9 nmol. This different antifertility effect could not be explained solely by altered tubal transport in inbred mice since the rate of transport was slightly accelerated in one stock (BALB/c) but not in another (CBA). In crossbred mice tubal transport was not significantly altered by antibody treatment.

At Day 3 ( $54-58$ h p.c.), the majority of embryos in control mice were at the 4-cell and 8-cell to morula stages in inbred and crossbred stock, respectively, but after antibody treatment they were mainly at the 4-cell stage in all 4 stocks. At Day 4 (78-82 $\mathrm{h}$ p.c.) the majority of embryos in control females had reached the blastocyst stage in all stocks, whereas after antibody treatment they had reached this stage in crossbred stock and relatively few had progressed so far in inbred stock.

The results indicate that there are two events in early gestation which are susceptible to passive immunization with anti-progesterone monoclonal antibody. The first of these occurs during cleavage shortly after the 4-cell stage when embryo development was arrested in two inbred stocks of mice. Antibody effects on cleavage were not direct since embryos cultured in the presence of high concentrations of antibody, or antibody saturated with progesterone, continued to develop in the normal way and formed blastocysts. The second event is the onset of implantation, an effect also influenced by genotype. The decidual cell reaction induced by intraluminal oil injection was blocked by antibody injected at 8 or $32 \mathrm{~h}$ p.c. in BALB/c females, but only when injected at $8 \mathrm{~h}$, and not at $32 \mathrm{~h}$ p.c., in $\mathrm{F}_{1}$ hybrid females. The results show that there is a greater resistance in two crossbred stocks compared with two inbred stocks to the effects of passive immunization against progesterone in early pregnancy.
\end{abstract}

\section{Introduction}

The isolation of an anti-progesterone monoclonal antibody that blocks pregnancy at an early stage provides an ideal opportunity to examine the ways by which progesterone acts on the female reproductive tract during the earliest stages of gestation. The use of an immunological rather than a surgical approach has demonstrated that passive immunization at $32 \mathrm{~h}$ after mating prevents the establishment of pregnancy in BALB/c mice whether the antibody is given by a single intravenous (i.v.) or intraperitoneal (i.p.) injection (Wright et al., 1982). The effect can be reserved by the

*Present address: Baylor College of Medicine, Department of Cell Biology, Texas Medical Center, Houston, Texas 77030, U.S.A. 
administration of exogenous progesterone (Rider et al., 1985). After antibody treatment mitotic activity in the uterine luminal and glandular epithelium at Day 3 post coitum (p.c.) is increased, whereas in uterine stromal cells at Days 4 and 5 p.c. it is significantly suppressed compared with that found in untreated animals. When endometrial sensitivity to a deciduogenic stimulus is determined by the intraluminal injection of oil at Day 4 , antibody treatment at $32 \mathrm{~h}$ p.c. clearly inhibits the increase in sensitivity normally associated with the onset of implantation (Rider et al., 1985, 1986). These findings are consistent with the classical view that passive immunization acts through the high-affinity binding of antigen by injected antibody and thereby prevents antigen from interacting with target cell receptors.

During the course of our studies two unexpected observations have emerged. Firstly, passive immunization at $32 \mathrm{~h}$ p.c. arrests normal embryonic development with a high proportion of fertilized eggs failing to reach the blastocyst stage (Wang et al., 1984). This suggests that the rate of cleavage in vivo is influenced by the availability of progesterone in circulation. Secondly, whereas a single dose of antibody blocks the establishment of pregnancy when injected at $32 \mathrm{~h}$ in BALB/c and CBA mice as described above, it is less effective in $F_{1}$ hybrid stock (CBA male $\times$ BALB/c female); there is only a transient disruption of the pattern of mitotic events associated with the onset of implantation, and implantation and subsequent embryo development appear to proceed normally (Rider et al., 1986). These findings imply that the sensitivity of these processes to passive immunization is influenced by genotype, and the present study has been designed to test this hypothesis further and to determine whether the antibody has a direct effect on embryo development.

\section{Materials and Methods}

Animals. Four stocks of mature virgin mice were used, two inbred lines (BALB/cJ, CBA/Ca), an outbred line (Tuck's no. I) and an $\mathrm{F}_{1}$ hybrid (CBA/Ca male $\times \mathrm{BALB} / \mathrm{cJ}$ female). They were housed in a light- $(14 \mathrm{~h}$ light:10 h dark, lights off $20: 00 \mathrm{~h})$ and temperature- $\left(22^{\circ} \mathrm{C}\right)$ controlled room and fed a mouse and rat diet (Labsure, The Christopher Hill Group, Poole, Dorset). Female mice were caged with males of the same stock overnight and examined the next morning for vaginal plugs (Day 1 of pregnancy). Mating was presumed to have taken place at 02:00 h, time 0 (Bronson et al., 1966).

Monoclonal antibody. Ascites fluid containing anti-progesterone monoclonal antibody (DB3) was produced and characterized as immunoglobulin $\mathrm{G}$ (IgG1) as described previously (Wright et al., 1982). The ascites fluid was pooled and its $\mathrm{IgG}$ concentration $(38.0 \mathrm{nmol} / \mathrm{ml})$ was measured in a Beckman Model E analytical ultracentrifuge equipped with Schlieren optics by comparison with a known concentration of IgG. Progesterone binding was tested by a radioligand binding assay (Wright $e t$ al., 1982) and aliquants of undiluted ascites fluid were stored at $-60^{\circ} \mathrm{C}$.

IgG was isolated from pooled DB3 ascites fluid by precipitation with saturated sodium sulphate $(18 \%)$ followed by DEAE-cellulose ion-exchange chromatography (elution gradient $0.01-0.1 \mathrm{M}$-phosphate, $\mathrm{pH} 8 \cdot 0$ ). the IgG concentration $(80 \mathrm{nmol} / \mathrm{ml})$ was measured by absorbance at $280 \mathrm{~nm}$ assuming a $\sum_{280}^{1 \%} 13.5$. Progesterone binding by the purified IgG was tested after serial dilution (1:2000 to $1: 16000$ ) in $0.05 \mathrm{~mol}$ sodium phosphate buffer $/ 1, \mathrm{pH} 7 \cdot 4$, using a radioligand assay (Wright et al., 1982). A volume of $100 \mu \mathrm{lgG}(8 \mathrm{nmol})$ after a dilution of $1: 6000$ bound $50 \%$ of a known quantity of $\left[{ }^{3} \mathrm{H}\right.$ ]progesterone (333 Bq, $0.08 \mathrm{pmol}$ ) (Amersham International, Bucks, U.K.).

Antibody effects on embryo development and pregnancy. To test the relative effects of antibody on embryonic development and the establishment of pregnancy in different stocks, mice were injected i.p. with $250 \mu \mathrm{l}$ ascites fluid, containing $9.5\left(B A L B / c, C B A, F_{1}\right)$ or 10.9 (Tuck's no. 1) nmol anti-progesterone IgG, 8 or $32 \mathrm{~h}$ after mating. These doses of antibody block pregnancy in BALB/c and CBA mice (Wang et al., 1984; Heap et al., 1984). Control females were given an equivalent volume $(250 \mu \mathrm{l})$ of $0.9 \%(\mathrm{w} / \mathrm{v}) \mathrm{NaCl}$ since the results were identical to those obtained with a control ascites fluid from a mouse myeloma (MOPC 1748). Autopsies were carried out between 10:00 and 14:00 $\mathrm{h}$ and blood samples were taken under ether anaesthesia by cardiac puncture and the number of corpora lutea were counted. In mice examined at Days 2, 3 and 4 the oviducts and uterine horns were flushed with phosphate-buffered saline (PBS) $\mathrm{pH} 7.4$ to recover embryos, whereas other animals were studied at Days 9 or 10 to record the number of normal implantation sites. The stage of cleavage was determined; embryos that had started to cavitate were scored as blastocysts. Some embryos were air-dried (Tarkowski; 1966) and stained with Giemsa to confirm the classification of embryonic stages.

Embryo culture. To determine whether antibody has a direct effect on embryo development, female BALB/c mice were superovulated by i.p. injections of 5 i.u. PMSG (Intervet, Cambridge, U.K.), followed $48 \mathrm{~h}$ later by 5 i.u. hCG (Intervet). After hCG injection, females were placed with BALB/c males and checked the next morning for the 
presence of a vaginal plug (Day 1). Two-cell stage embryos were flushed from the oviducts $42-44 \mathrm{~h}$ after hCG treatment and placed in an embryo culture medium, BMOC-3 (Brinster, 1970). Bovine serum albumin $(60.4 \mathrm{nmol} / \mathrm{ml})$ and purified DB3 IgG $(0-7 \cdot 3 \mathrm{nmol} / \mathrm{ml})$ were added to the medium on the day of culture. The highest concentration of IgG used was $\sim 7$-fold greater than the minimum effective dose of antibody required to block pregnancy in BALB/c mice (Heap et al., 1984). A minimum of 10 embryos were placed in $50 \mu l$ droplets of medium in $35 \times 10 \mathrm{~mm}$ Nunclon culture dishes (Nunc, Kamstrup, Denmark) under paraffin oil. Cultures were incubated at $37.5^{\circ} \mathrm{C}$ in $5 \% \mathrm{CO}_{2}$ in humidified air and embryonic development was assessed by light microscopy after 24 and $54 \mathrm{~h}$ of culture $(68$ and $98 \mathrm{~h}$ after hCG treatment). Some embryos were air-dried (Tarkowski, 1966) and stained with Giemsa at the end of culture to confirm the classification of the stage of embryonic development.

To test whether antibody in combination with progesterone affected development, progesterone was added to cultures containing $7.3 \mathrm{nmol} \mathrm{IgG} / \mathrm{ml}$. Previous analysis of the binding characteristics of DB3 ascites fluid (Scatchard, 1949) confirmed that I mol IgG bound approximately 2 mol progesterone (Wright et al., 1982; V. Rider, unpublished results). Culture medium was prepared to contain $7.3 \mathrm{nmol}$ or $15 \mathrm{nmol}$ progesterone $/ \mathrm{ml}$ to ensure that 50 or $100 \%$ of antibody binding sites were occupied by steroid. Control cultures contained the same amount of IgG and ethanol $(5 \mu \mathrm{l} / \mathrm{ml})$ as those treated with progesterone. Two-cell stage embryos were collected as described previously and were placed in $96 \mathrm{~F}$ microtest plates (Nunc) containing $200 \mu \mathrm{l}$ medium and at least 10 embryos per well. Cultures were incubated at $37.5^{\circ} \mathrm{C}$ in $5 \% \mathrm{CO}_{2}$ in humidified air without paraffin oil. Development was assessed after 24 and $54 \mathrm{~h}$ of culture and some embryos were air-dried as described previously.

Endometrial sensitivity. Mice $\left(\mathrm{F}_{1}\right.$ hybrid) were placed with vasectomized males and checked the next morning for vaginal plugs. Mated females received a single i.p. injection of antibody $(9.5 \mathrm{nmol} \mathrm{IgG)} \mathrm{or} 0.9 \%(\mathrm{w} / \mathrm{v}) \mathrm{NaCl} 8 \mathrm{~h}$ after mating. At 16:00 h on Day 4 p.c., $0.01 \mathrm{ml}$ sesame oil was injected into one uterine horn as described previously (Rider et al., 1985). One group of mice treated with monoclonal antibody received daily subcutaneous injections of steroids $(6.4 \mu \mathrm{mol}$ progesterone, $73 \mathrm{pmol}$ oestradiol) beginning at the time of the intraluminal oil injection to ensure that the failure of a uterus to undergo a decidual cell reaction was not due to inadequate hormonal support after stimulation. The uterine horns were removed and weighed $72 \mathrm{~h}$ after intraluminal oil injection.

Radioimmunoassay. Plasma progesterone concentrations were measured by radioimmunoassay using the technique described by Rider et al. (1986). The sensitivity of the assay was $0.09 \pm 0.2 \mathrm{pmol} /$ assay tube (calculated from $2 \times$ s.d. below the value at zero concentration). The intra- and inter-assay coefficients of variation were $18 \cdot 2$ and $12.8 \%$, respectively. Adding $3.18 \mathrm{pmol} / \mathrm{ml}$ and $6.37 \mathrm{pmol} / \mathrm{ml}$ progesterone to $1.0 \mathrm{ml}$ plasma from male mice gave values of $3.07 \pm 0.2$ and $6.27 \pm 0.5 \mathrm{pmol} / \mathrm{ml}$, respectively ( 6 observations).

Siatistical analysis. The experimental results are given as means \pm s.e.m. Mean differences between groups were considered to be statistically significant if an appropriate test gave a $P$ value of $<0 \cdot 05$. Differences in the number of pregnant mice for antibody and saline-control treatments were compared using Bayesian methods between proportions (Walters, 1986). Mean differences between groups were tested by Student's $t$ test.

With regard to the effect of antibody treatment on tubal transport, the proportion of embryos in the oviduct was very often near the extremes of the permissible range ( 0 to 1$)$, so that a rigorous analysis was inevitably rather difficult, and two separate investigations were carried out. The proportions were first transformed onto the logistic scale and subjected to an analysis of variance, with 'time' and 'treatment' as the factors for each 'stock'. The purpose of the transformation was to render the observed variables (proportions) more amenable to the analysis of variance technique (see Cox, 1970). The second analysis consisted of comparing the average values of the proportions for the various groups of animals, using the method described by Walters (1986). Essentially, 95\% confidence limits are calculated for the relevant differences, and inferences then based on whether the limits do, or do not, embrace zero.

\section{Results}

\section{Pregnancy blocking effect}

Injections of 8 to $10 \mathrm{nmol}$ anti-progesterone monoclonal antibody at $32 \mathrm{~h} p . c$. blocked pregnancy when autopsies were performed at Day 10 p.c. in BALB/c $(0$ pregnant of 5 treated females) and CBA (0/6) stock, in contrast to results in control females (BALB/c 7/10; CBA, 14/14). Pregnancy rates in $\mathrm{F}_{1}$ hybrid or outbred stocks were less affected by antibody treatment $\left(\mathrm{F}_{1}\right.$ hybrid, 4/5; Tuck's no. 1, 5/7), the results being similar $(P>0.05)$ to those in control mice $\left(F_{1}\right.$ hybrid, $4 / 5$; Tuck's no. 1, 5/6).

\section{Tubal transport}

The question to consider is whether the difference in response between inbred and crossbred stock was due to altered tubal transport of embryos after antibody administration. At Day 3 
Table 1. Effect of passive immunization with anti-progesterone monoclonal antibody on tubal transport in two inbred (BALB/cJ, CBA/Ca) and two crossbred $\left(\mathrm{F}_{1}\right.$ hybrid $\mathrm{CBA} / \mathrm{Ca} \sigma^{*} \times \mathrm{BALB} / \mathrm{cJ}$ \% ; Tuck's no. 1) stocks of mice; females were injected i.p. with $250 \mu \mathrm{l}$ antibody $(9 \cdot 5-10.9 \mathrm{nmol} \mathrm{IgG}$ in ascites fluid) or $0.9 \%$ $\mathrm{NaCl}$ (control) $32 \mathrm{~h}$ after mating

\begin{tabular}{|c|c|c|c|c|c|c|}
\hline \multirow[b]{2}{*}{ Stock } & \multirow[b]{2}{*}{ Treatment } & \multirow[b]{2}{*}{$\begin{array}{l}\text { Day of autopsy } \\
\text { (no. of animals) }\end{array}$} & \multirow[b]{2}{*}{$\begin{array}{c}\text { No. of CL } \\
\text { (mean } \pm \text { s.e.m.) }\end{array}$} & \multicolumn{3}{|c|}{ Embryos } \\
\hline & & & & $\begin{array}{c}\text { Total no. } \\
\text { recovered } \\
\text { (mean/female) }\end{array}$ & $\begin{array}{l}\text { No. in } \\
\text { oviduct } \\
(\%)\end{array}$ & $\begin{array}{c}\text { No. in } \\
\text { uterus } \\
(\%)\end{array}$ \\
\hline \multirow[t]{2}{*}{$\mathrm{BALB} / \mathrm{c}$} & $\begin{array}{l}\text { Antibody } \\
\text { Control }\end{array}$ & $\begin{array}{ll}3 & (7) \\
3 & (7)\end{array}$ & $\begin{array}{l}8 \cdot 4 \pm 1 \cdot 2^{\mathrm{a}, \mathrm{d}} \\
8 \cdot 0 \pm 0 \cdot 5^{\mathrm{b}}\end{array}$ & $\begin{array}{ll}42 & (6.0) \\
46 & (6.4)\end{array}$ & $\begin{array}{ll}29 & (69) \\
43 & (96)\end{array}$ & $\begin{array}{rr}13(31)^{k} \\
2 & (4)^{k}\end{array}$ \\
\hline & $\begin{array}{l}\text { Antibody } \\
\text { Control }\end{array}$ & $\begin{array}{ll}4 & (9) \\
4 & (9)\end{array}$ & $\begin{array}{l}9 \cdot 3 \pm 0 \cdot 4^{h} \\
9 \cdot 8 \pm 0 \cdot 4^{i}\end{array}$ & $\begin{array}{l}45^{*}(5 \cdot 0) \\
58 *(6 \cdot 4)\end{array}$ & $\begin{array}{ll}3 & (7) \\
1 & (2)\end{array}$ & $\begin{array}{ll}42 & (93) \\
57 & (98)\end{array}$ \\
\hline \multirow[t]{2}{*}{ CBA } & $\begin{array}{l}\text { Antibody } \\
\text { Control }\end{array}$ & $\begin{array}{ll}3 & (6) \\
3 & (7)\end{array}$ & $\begin{array}{l}8 \cdot 8 \pm 0 \cdot 8^{\mathrm{e}} \\
7 \cdot 4 \pm 0 \cdot 4^{\mathrm{c} . \mathrm{f}}\end{array}$ & $\begin{array}{ll}31 & (5 \cdot 2) \\
37 & (5 \cdot 3)\end{array}$ & $\begin{array}{l}31(100) \\
30(81)\end{array}$ & $\begin{array}{rr}0 & (0) \\
7 & (19)\end{array}$ \\
\hline & $\begin{array}{l}\text { Antibody } \\
\text { Control }\end{array}$ & $\begin{array}{ll}4 & (7) \\
4 & (7)\end{array}$ & $\begin{array}{l}8 \cdot 3 \pm 1 \cdot 1^{g} \\
8 \cdot 6 \pm 0.8^{j}\end{array}$ & $\begin{array}{ll}26 & (3 \cdot 5) \\
42 & (6.0)\end{array}$ & $\begin{array}{rr}6 & (23) \\
0 & (0)\end{array}$ & $\begin{array}{l}20(77) \\
42(100)\end{array}$ \\
\hline \multirow[t]{2}{*}{$F_{1}$ hybrid } & $\begin{array}{l}\text { Antibody } \\
\text { Control }\end{array}$ & $\begin{array}{l}3(10) \\
3(6)\end{array}$ & $\begin{array}{r}11 \cdot 8 \pm 0.6^{\mathrm{a}} \\
9 \cdot 0 \pm 0.5^{\mathrm{c}}\end{array}$ & $\begin{array}{ll}73 & (7 \cdot 3) \\
38 & (6 \cdot 3)\end{array}$ & $\begin{array}{ll}69 & (95) \\
32 & (84)\end{array}$ & $\begin{array}{lr}4 & (5) \\
6 & (16)\end{array}$ \\
\hline & $\begin{array}{l}\text { Antibody } \\
\text { Control }\end{array}$ & $\begin{array}{ll}4 & (8) \\
4 & (8)\end{array}$ & $\begin{array}{l}9 \cdot 0 \pm 0.3 \\
9 \cdot 4 \pm 0.7\end{array}$ & $\begin{array}{ll}63 & (7.9) \\
61 & (7.6)\end{array}$ & $\begin{array}{ll}0 & (0) \\
0 & (0)\end{array}$ & $\begin{array}{l}63(100) \\
61(100)\end{array}$ \\
\hline \multirow[t]{2}{*}{ Tuck's no. 1} & $\begin{array}{l}\text { Antibody } \\
\text { Control }\end{array}$ & $\begin{array}{ll}3 & (9) \\
3 & (9)\end{array}$ & $\begin{array}{l}12 \cdot 6 \pm 0.9^{\mathrm{d}, \mathrm{e}} \\
11 \cdot 2 \pm 0.9^{\mathrm{b}, \mathrm{f}}\end{array}$ & $\begin{array}{r}107(11.9) \\
97(10 \cdot 7)\end{array}$ & $\begin{array}{r}107(100) \\
76(78)\end{array}$ & $\begin{array}{rr}0 & (0) \\
21 & (22)\end{array}$ \\
\hline & $\begin{array}{l}\text { Antibody } \\
\text { Control }\end{array}$ & $\begin{array}{l}4(9) \\
4(8)\end{array}$ & $\begin{array}{l}12 \cdot 7 \pm 0 \cdot 5^{\mathrm{g} . \mathrm{h}} \\
13 \cdot 6 \pm 0 \cdot 7^{\mathrm{i}, \mathrm{j}}\end{array}$ & $\begin{array}{r}91(11.4) \\
117(13.0)\end{array}$ & $\begin{array}{ll}0 & (0) \\
0 & (0)\end{array}$ & $\begin{array}{r}91(100) \\
117(100)\end{array}$ \\
\hline
\end{tabular}

*Excludes two animals in each group in which no fertilized eggs were found.

Values with the same superscript letter are significantly different by Student's $t$ test; a,b,c: $P<0.05$; d,e,f,g: $P<0.01$; h.i.j: $P<0.001$; or by confidence limit method of analysis (k: $P<0.01$, but see text).

(54-58 $\mathrm{h}$ p.c.) the majority of embryos were found in the oviduct of control females in all 4 stocks of mice (Table 1). After antibody treatment there was an acceleration of tubal transport in BALB/c mice with $31 \%$ of the embryos being found prematurely in the uterus. This finding was on the borderline of statistical significance $(P<0 \cdot 10)$ by the analysis of variance method, but significant $(P<0.01)$ by the confidence limit method of analysis. Accelerated tubal transport was not found in CBA mice (nor in the two crossbred stocks) and if anything there was a slight retardation in the rate of transport (Table 1) suggesting that antibody efficacy in inbred stocks was unrelated to an effect on tubal transport of embryos. At Day 4 ( $78-82 \mathrm{~h}$ p.c.) most embryos were located in the uterus regardless of treatment. In CBA mice only, there was a slight retardation in tubal transport after antibody treatment with $77 \%$ of the embryos being recovered from the uterine horns compared with $100 \%$ in control females $(P>0.05$; Table 1$)$. The average number of corpora lutea per female was higher in crossbred than in inbred mice $(P<0.02$; Table 1$)$.

\section{Classification of development in different stocks}

Since the difference in response of inbred and crossbred stocks to antibody treatment could not be explained solely in terms of altered tubal transport, further studies were carried out on differences in the rate of embryo development (Fig. 1). The majority of embryos recovered from control females at Day 3 (54-58 h p.c.) were at the 4-cell stage in BALB/c and CBA mice, but in $F_{1}$ and Tuck's no. 1 the majority had undergone compaction and were at the 8-cell to morula stage, at 
(a) $54-58 \mathrm{~h}$
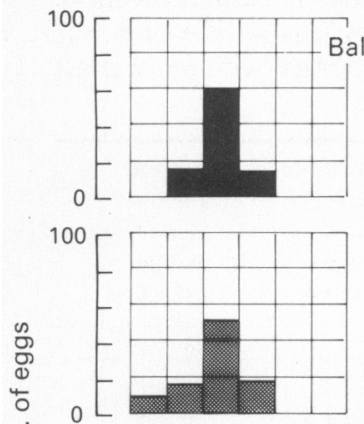

(c)

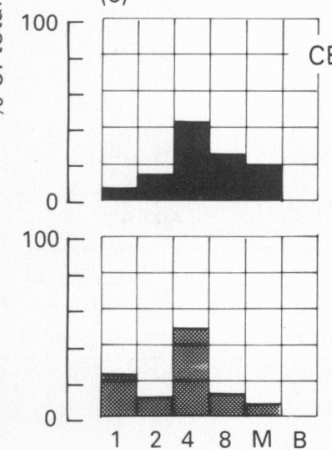

$78-82 \mathrm{~h}$
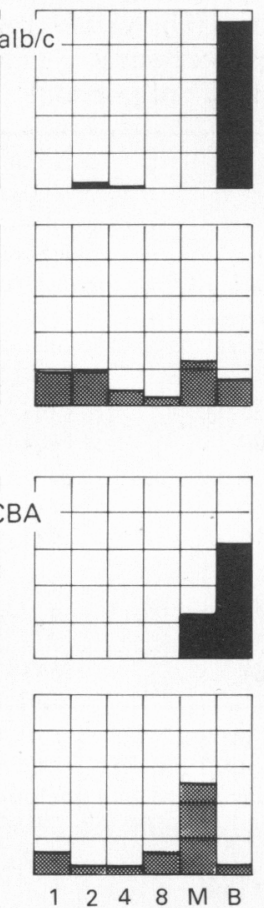

Stage of (b) $54-58 \mathrm{~h}$
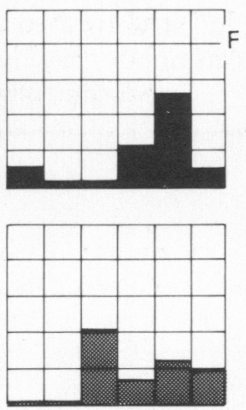

(d)
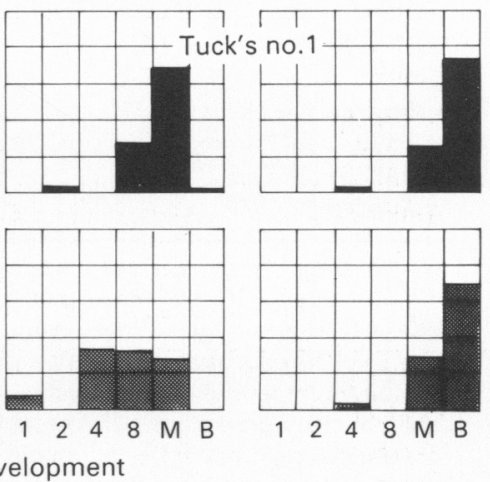

$78-82 \mathrm{~h}$
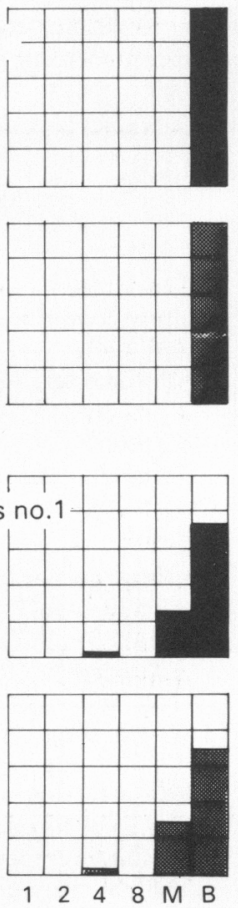

Fig. 1. Embryo classification in two inbred (a, BALB/cJ; b, CBA/Ca) and two crossbred (c, $F_{1}$ hybrid, CBA/Ca male $\times$ BALB/cJ female; d, Tuck's no. 1) stocks of mice at Day 3 (54-58 h post coitum, p.c.) and Day 4 (78-82 h p.c.). Mice were injected intraperitoneally at $32 \mathrm{~h}$ p.c. with $250 \mu \mathrm{l} \quad 0.9 \% \mathrm{NaCl}$ (control, solid bars) or anti-progesterone monoclonal antibody $\left(9.5-10.9 \mathrm{nmol}\right.$ anti-progesterone immunoglobulin $\mathrm{G}_{1}$ in $0.9 \% \mathrm{NaCl}$ ) (stippled bars). At autopsy eggs were flushed from the oviducts and uterine horns with phosphate-buffered saline and the stage of development determined. Stages were classified as 1-cell (1), 2-cell (2), 3- to 4-cell (4), >4-cell (8), >8-cell (M, morula), and after cavitation (B, blastocyst). Results are expressed as percentages of the total number of eggs recovered from the oviduct and uterus. Number of embryos recovered: (a) 45 and 42 at 54-58 h (control and treated, respectively); 26 and 45 at $78-82 \mathrm{~h}$; (b) 37 and 31 at $54-58 \mathrm{~h} ; 58$ and 42 at $78-82 \mathrm{~h}$; (c) 38 and 73 at $54-58 \mathrm{~h} ; 61$ and 63 at $78-82 \mathrm{~h}$; (d) 91 and 82 at $54-58 \mathrm{~h} ; 106$ and 82 at $78-82 \mathrm{~h}$. Number of animals for each stock: (a) 32, (b) 27, (c) 32, (d) 32 .

least 1-cell division more advanced than in their inbred counterparts. After antibody treatment at $32 \mathrm{~h}$ after mating most eggs were at the 4 -cell stage in all four stocks (BALB/c, 50\%; CBA, 48\%; $\mathrm{F}_{1}$ hybrid, $41 \%$; Tuck's no. $1,35 \%$ ).

By Day 4 (78-82 h) the majority of embryos had reached the blastocyst stage in control females (BALB/c, 93\%; CBA, 62\%; $F_{1}$ hybrid, 100\%; Tuck's no. 1, 74\%). After antibody treatment, however, the percentage that had developed to the blastocyst stage differed greatly between stocks (BALB/c, 16\%; CBA, 4\%; $F_{1}$ hybrid, 100\%; Tuck's no. 1, 69\%). In the inbred stocks, many embryos failed to cavitate although they appeared to have undergone compaction. The number of degenerate eggs was similar in control and antibody-treated inbred mice indicating that the treatment did not cause abnormal cleavage. Degenerate eggs were rarely seen in the crossbred stocks. 
Table 2. Purified anti-progesterone monoclonal antibody (IgG) fails to affect the development of BALB/cJ mouse embryos in vitro (a) with increasing concentrations of antibody, (b) in the presence of antibody with saturating concentrations of progesterone

\begin{tabular}{|c|c|c|c|}
\hline \multirow[b]{2}{*}{ Culture conditions } & \multirow[b]{2}{*}{$\begin{array}{l}\text { Total no. of } \\
\text { embryos }\end{array}$} & \multicolumn{2}{|c|}{$\begin{array}{l}\text { Embryonic development } \\
\text { after } 54 \mathrm{~h} \text { of culture }\end{array}$} \\
\hline & & $\begin{array}{c}\text { No. before } \\
\text { cavitation } \\
(\%)\end{array}$ & $\begin{array}{c}\text { No. of } \\
\text { blastocysts } \\
(\%)\end{array}$ \\
\hline \multicolumn{4}{|c|}{ (a) Purified IgG $(\mathrm{nmol} / \mathrm{ml})$} \\
\hline 0 & 123 & $17(14)$ & $106(86)$ \\
\hline 0.0067 & 100 & $14(14)$ & $86(86)$ \\
\hline 0.067 & 106 & $10(9)$ & $96(91)$ \\
\hline 0.67 & 116 & $18(16)$ & $98(84)$ \\
\hline $6 \cdot 7$ & 114 & $19(17)$ & $95(83)$ \\
\hline \multicolumn{4}{|c|}{ (b) Progesterone effect } \\
\hline $0.5 \mathrm{P}+\mathrm{IgG}^{*}$ & 82 & $18(22)$ & $64(78)$ \\
\hline $1.0 \mathrm{P}+\mathrm{IgG} \dagger$ & 81 & $19(23)$ & $62(77)$ \\
\hline Control+ & 84 & $16(19)$ & $68(81)$ \\
\hline
\end{tabular}

Two-cell stage mouse embryos were collected from the oviducts of BALB/cJ mice $42-44 \mathrm{~h}$ after hCG treatment and cultured for $54 \mathrm{~h}$ in medium containing purified anti-progesterone IgG. Progesterone was added to some cultures to occupy one-half $(0.5 \mathrm{P})$ or to saturate fully $(1.0 \mathrm{P})$ antibody binding sites. Embryos that had started to cavitate were scored as blastocysts.

$* 7.3 \mathrm{nmol}$ progesterone $/ \mathrm{ml}+7.3 \mathrm{nmol} \mathrm{IgG} / \mathrm{ml}$.

$+15 \mathrm{nmol}$ progesterone $/ \mathrm{ml}+7 \cdot 3 \mathrm{nmol} \mathrm{IgG/ml}$.

+ Vehicle $(5 \mu \mathrm{l}$ ethanol $)+7.3 \mathrm{nmol} \mathrm{IgG} / \mathrm{ml}$.

Table 3. Passive immunization with anti-progesterone monoclonal antibody at $8 \mathrm{~h}$ after mating blocks pregnancy in inbred $(\mathrm{BALB} / \mathrm{cJ})$ and $\mathrm{F}_{1}$ hybrid $(\mathrm{CBA} / \mathrm{Ca} \hat{\sigma} \times \mathrm{BALB} / \mathrm{cJ} q)$ mice

\begin{tabular}{|c|c|c|c|c|c|c|}
\hline \multirow[b]{2}{*}{ Strain } & \multirow[b]{2}{*}{ Treatment } & \multirow{2}{*}{$\begin{array}{l}\text { No. pregnant/ } \\
\text { no. treated }\end{array}$} & \multirow{2}{*}{$\begin{array}{c}\text { No. of CL } \\
\text { (mean } \pm \text { s.e.m.) }\end{array}$} & \multirow{2}{*}{$\begin{array}{l}\text { Total no. of } \\
\text { implantation } \\
\text { sites }\end{array}$} & \multicolumn{2}{|c|}{$\begin{array}{l}\text { Plasma progesterone } \\
\text { (nmol/l) }\end{array}$} \\
\hline & & & & & Pregnant & Non-pregnant \\
\hline $\mathrm{BALB} / \mathrm{c}$ & $\begin{array}{l}\text { Antibody } \\
\text { Saline }\end{array}$ & $\begin{array}{l}0 / 6^{* *} \\
5 / 6\end{array}$ & $\begin{array}{l}9 \cdot 3 \pm 2 \cdot 9 \\
9 \cdot 3 \pm 2 \cdot 4\end{array}$ & $\begin{array}{c}0 \\
8 \cdot 8 \pm 3 \cdot 0\end{array}$ & $88.4 \pm 7.0(5)^{\mathrm{a}}$ & $322.8 \pm \frac{ \pm}{6 \cdot 3} 46.8(6)^{a}$ \\
\hline$F_{1}$ hybrid & $\begin{array}{l}\text { Antibody } \\
\text { Saline }\end{array}$ & $\begin{array}{l}1 / 6^{*} \\
5 / 6\end{array}$ & $\begin{array}{r}10 \cdot 6 \pm 4 \cdot 0 \\
9 \cdot 3 \pm 0 \cdot 2\end{array}$ & $\begin{array}{c}12 \\
8 \cdot 4 \pm 0 \cdot 3\end{array}$ & $\begin{array}{c}1043 \cdot 7 \quad \text { (1) } \\
99 \cdot 9 \pm 3 \cdot 5 \text { (5) }\end{array}$ & $250 \cdot 7 \underset{4 \cdot 7}{ \pm}$ \\
\hline
\end{tabular}

Animals were given a single intraperitoneal injection of ascites fluid containing $9.5 \mathrm{nmol}$ immunoglobulin $\mathrm{G}$ (antibody) or an equal volume $(250 \mu \mathrm{l})$ of $0.9 \%(\mathrm{w} / \mathrm{v}) \mathrm{NaCl}$ (saline). Autopsies were carried out at Day 9 after mating. Progesterone concentrations in plasma were determined by radioimmunoassay and are means \pm s.e.m. Numbers in parentheses represent no. of animals.

Difference between treated and control animals is significant at ${ }^{*} P<0.05$ and ${ }^{* *} P<0.01$ (Bayesian method for comparison of two proportions, Walters, 1986). Values with same superscript letter are significantly different by Student's $t$ test $(P<0.05)$.

\section{Effect of antibody on development in vitro}

To test whether the antibody had a direct effect on development, embryos from BALB/c mice were cultured in the presence of different concentrations of purified IgG. In control cultures, $>80 \%$ of the 2-cell embryos recovered $42-44 \mathrm{~h}$ after hCG treatment were beginning to cavitate after a further $54 \mathrm{~h}$ in culture (Table 2). Addition of up to $7.3 \mathrm{nmol}$ purified DB3 $\mathrm{IgG} / \mathrm{ml}$ did not significantly reduce the number of embryos which reached the blastocyst stage at $54 \mathrm{~h}$. After $24 \mathrm{~h}$ in 


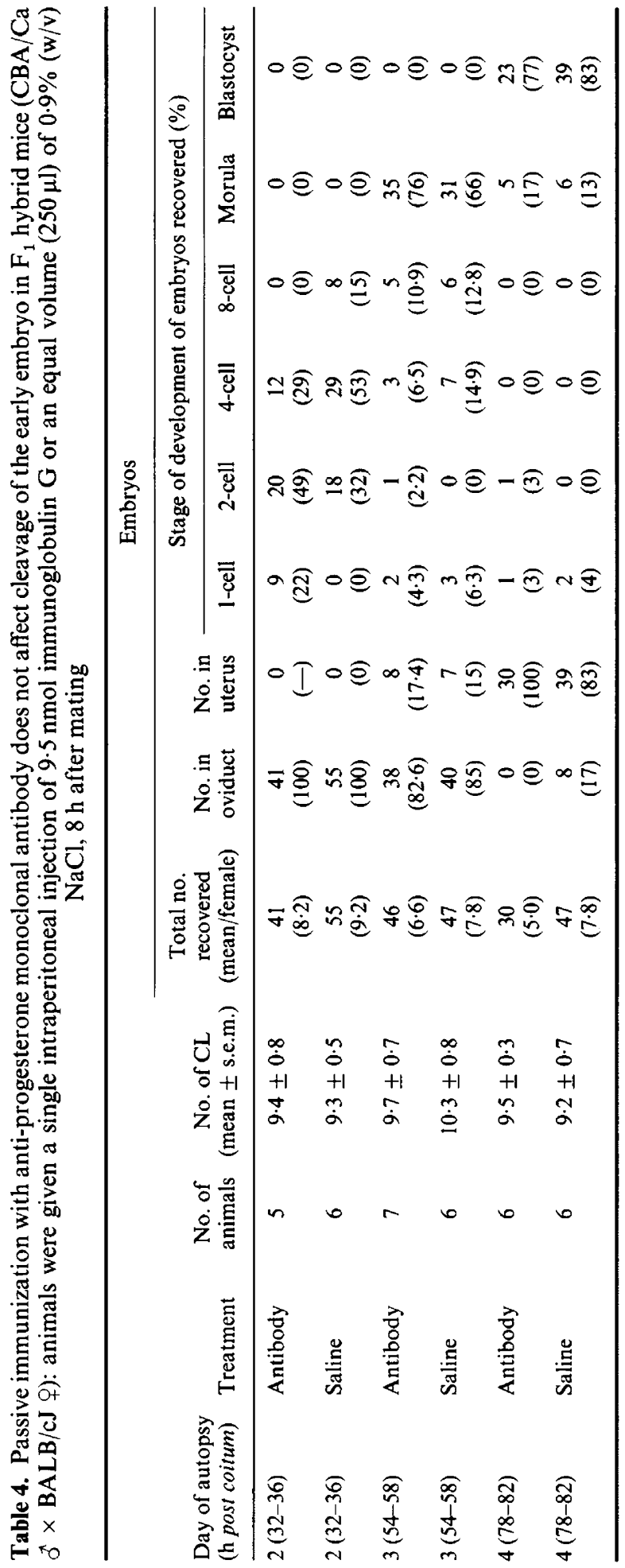


Table 5. The effect of anti-progesterone monoclonal antibody and the intraluminal injection of oil on induction of the decidual cell reaction (DCR) in $\mathrm{F}_{1}(\mathrm{CBA} / \mathrm{Ca}$ $\hat{0} \times \mathrm{BALB} / \mathrm{cJ}$ ) mice

\begin{tabular}{lcccccc}
\hline & \multirow{2}{*}{$\begin{array}{c}\text { No. of } \\
\text { Group }\end{array}$} & \multicolumn{2}{c}{ Treatment } & & \multicolumn{2}{c}{ Mean \pm s.e.m. uterine weight (mg) } \\
\cline { 7 - 8 } \cline { 6 - 7 } & animals & $8 \mathrm{~h}$ & $4-7$ days* $^{*}$ & & Injected horn & Non-injected horn \\
\hline 1 & 4 & Antibody & - & & $36 \cdot 0 \pm 4 \cdot 6^{\mathrm{a}}$ & $33 \cdot 5 \pm 4 \cdot 4$ \\
3 & 4 & Saline & - & & $197 \cdot 0 \pm 44 \cdot 1^{\mathrm{a}, \mathrm{b}}$ & $31 \cdot 5 \pm 3 \cdot 5^{\mathrm{b}}$ \\
& 6 & Antibody & Steroids & & $28 \cdot 8 \pm 1 \cdot 7$ & $27 \cdot 2 \pm 2 \cdot 7$ \\
\hline
\end{tabular}

Nulliparous $F_{1}$ females were placed with vasectomized males and checked the next morning for the presence of a vaginal plug (Day 1 of pregnancy). Mated females received a single i.p. injection of antibody containing $9.5 \mathrm{nmol}$ immunoglobulin $\mathrm{G}$ or an equivalent volume $(250 \mu \mathrm{l})$ of $0.9 \% \mathrm{NaCl}(\mathrm{w} / \mathrm{v})$ at $8 \mathrm{~h}$ after mating. At $16: 00 \mathrm{~h}$ on Day 4 of pregnancy $0.01 \mathrm{ml}$ sesame oil was injected into one uterine horn to induce the DCR. Autopsies were carried out $72 \mathrm{~h}$ later and the uterine horns were weighed.

*Steroids $(6.4 \mu \mathrm{mol}$ progesterone and $73 \mathrm{pmol}$ oestradiol in $0.1 \mathrm{ml}$ sesame oil) were injected subcutaneously after intraluminal injection of $0.01 \mathrm{ml}$ sesame oil into one uterine horn at 16:00 h on Day 4.

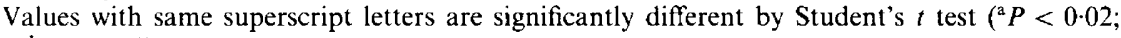
$\left.{ }^{\mathrm{b}} P<0.01\right)$.

culture embryos had reached the 4- to 8-cell stage at each dose tested, confirming that the rate of cleavage divisions was unaffected by antibody. Progesterone added to cultures containing DB3 IgG did not significantly reduce the number of embryos undergoing cavitation after $54 \mathrm{~h}$ of culture (Table 5).

\section{Time of injection}

In view of the more rapid rate of development seen in the crossbred stocks, we designed an experiment to test whether antibody would block pregnancy in $F_{1}$ hybrid mice if injected on the morning when the copulatory plug was detected. The hypothesis was that, if the antibody is most effective at a critical stage of early development, the faster rate of cleavage in crossbred stock may have precluded any effect of passive immunization at $32 \mathrm{~h} \mathrm{p.c.} \mathrm{A} \mathrm{single} \mathrm{injection} \mathrm{of} \mathrm{antibody} \mathrm{was}$ therefore given at 10:00 h on Day 1 (estimated to be $8 \mathrm{~h}$ after mating). This treatment blocked pregnancy in 5 of $6 F_{1}$ hybrid and 6 of $6 \mathrm{BALB} / \mathrm{c}$ females (Table 3). In the one $\mathrm{F}_{1}$ hybrid female that remained pregnant the number and macroscopic appearance of implantation sites was normal. Plasmal progesterone concentrations in antibody-treated females (non-pregnant) were 2- to 3-fold greater than those of controls, and in the single $F_{1}$ female that remained pregnant they were 10 -fold higher than normal (Table 3).

In $F_{1}$ hybrid mice the pregnancy block was not associated with developmental arrest. At Day 2 the majority of embryos were at the 2-cell stage $(49 \%)$ in the antibody group compared with the 4-cell stage $(53 \%)$ in the control group, but by Days 3 and 4 the rate of development was indistinguishable between the two groups (Table 4). The majority of embryos in control $F_{1}$ hybrid mice at Day 2(53\% at 4-cell stage, Table 4) were at a similar stage to those in control inbred mice at Day 3 (BALB/c, $60 \%$ and CBA, $42 \%$ at 4-cell stage; Fig. 1), confirming the more rapid rate of development in the crossbred compared with the inbred stocks.

\section{Endometrial sensitivity}

To throw further light on the mechanism by which pregnancy is blocked in $F_{1}$ hybrid mice by antibody treatment at $8 \mathrm{~h}$ after mating, we tested endometrial sensitivity in these animals (Table 5). After passive immunization the endometrium was insensitive to a deciduogenic stimulus at the 
expected time (Day 5) since there was no increase in the weight of the uterine horn which received an intraluminal injection of oil. In control mice there was an increase of about 10-fold in the weight of the injected horn. The failure of the endometrium to respond to a deciduogenic stimulus in $F_{1}$ mice was not due to a deficiency of ovarian steroids after stimulation since exogenous progesterone and oestradiol treatment did not increase uterine weight (Table 5). Thus, the endometrium was refractory at the time of intraluminal oil injection (Day 4 p.c.).

\section{Discussion}

The present findings show that there are two events during the establishment of pregnancy in the mouse that are susceptible to passive immunization against progesterone, namely, preimplantation embryo development at about the 4-cell stage and the increase in endometrial sensitivity associated with the onset of implantation at Day 4 p.c. The effect during the early stages of cleavage seems to be an indirect rather than a direct one since we could find no evidence for arrest when BALB/c embryos were cultured in the presence of antibody. The highest concentration of antibody used was $7 \cdot 3 \mathrm{nmol} / \mathrm{ml}$ compared with an intraperitoneal injection of $9.5 \mathrm{nmol}$, so that embryos were probably exposed to a concentration in vitro which was at least as high as that in vivo. When antibodybinding sites were occupied by progesterone there was also no effect on blastocyst development so that retardation of development in vivo was not due to an effect of antibody and its associated progesterone, or to progesterone itself. Babinet et al. (1977) reported that $\mathrm{F}(\mathrm{ab})$ fragments prepared from rabbit immunoglobulins prevented compaction of cultured mouse embryos in vitro. We have not excluded the possibility that $\mathrm{F}(\mathrm{ab})$ fragments may be formed from injected antibody and that they penetrate into the oviduct lumen and retard embryonic development. Experiments with $\mathrm{DB} 3 \mathrm{~F}(\mathrm{ab})$ fragment injected in vivo, however, show that it does not produce arrested development (V. Rider, unpublished observations).

If passive immunization affects early embryo development by an indirect mechanism, factors in the luminal environment of the oviduct may be responsible for cleavage arrest. When embryos are cultured in vitro, development progresses normally in a simple defined medium containing lactate and pyruvate as energy sources (Brinster, 1965). Pyruvate and lactate concentrations in the oviduct are known to fluctuate during the oestrous cycle in response to hormone changes (Nieder \& Corder, 1982), so that disruption of the normal pattern of circulating progesterone concentration by passive immunization may result in a deleterious substrate deficiency. The presence of inhibitory compounds in the oviduct must also be considered since oestradiol stimulates the rabbit oviduct to produce a low molecular weight inhibitor of embryo development $\left(M_{\mathrm{r}}<10000\right.$; Stone et al., 1977), and a family of sulphated glycoproteins whose function remains uncertain (Oliphant et al., $1984 \mathrm{a}, \mathrm{b}$ ). Antibody administration prolongs oestrogen-like effects in BALB/c mice as reflected by the pattern of mitotic activity in the glandular and luminal epithelia of the endometrium (Rider $e t$ al., 1985) though plasma concentrations of oestradiol-17 $\beta$ at Day 4 p.c. are normal (V. Rider, unpublished observations). Passive immunization may extend, therefore, the time when the reproductive tract is exposed to oestrogen action, particularly if a substantial proportion of progesterone in circulation is bound by antibody and unable to interact with target cell receptors.

The present study further confirms that these effects of passive immunization in blocking the establishment of pregnancy are influenced by genotype. Antibody injected at $32 \mathrm{~h}$ p.c. was most effective in two inbred, and much less so in two crossbred stocks of mice using a dosage of 9.5-10.9 nmol. The effect of genotype on antibody efficacy was not due solely to differences in the rate of tubal transport since although the rate was slightly accelerated in BALB/c stock, this did not occur in CBA mice, a stock in which the antibody was almost as effective as in BALB/c females (Wang et al., 1984). In crossbred mice the rate of tubal transport was not significantly different after antibody treatment. Although some embryos were retained longer in the oviduct than in control females, an insufficient number were retained to conclude that this was the reason for the lack of antibody efficacy. In fact, the mean number of embryos recovered for each female at Day 4 p.c. 
when all embryos had reached the uterus was similar in treated and control females. Therefore, alternative explanations should be considered for the striking difference in the anti-fertility effects of antibody in inbred and crossbred females.

Embryo development assessed at standard times was notably different between the stocks of mice used in these experiments. At Day 3 (54-58 h p.c.) embryos of the inbred stocks were mostly at the 4-cell stage, whereas those of crossbred stocks had reached the morula stage. Previous workers have shown that genetic differences in embryo development are related to the time when cleavage begins rather than to the rate of cleavage (McLaren \& Bowman, 1973), that paternal and maternal genotype can have significant effects on the timing of first cleavage (Shire \& Whitten, 1980a, b; Niwa et al., 1980), and that a gene associated with the major histocompatibility complex (H-2 preimplantation embryo development gene) influences not only the time of first cleavage but also the rate of preimplantation embryo development (Goldbard \& Warner, 1982; Goldbard et al., 1982; Warner et al., 1984). According to our findings, anti-progesterone monoclonal antibody given at $32 \mathrm{~h}$ p.c. retards the rate of preimplantation embryo development at about the 4-cell stage in inbred stocks, as in ferrets (Rider \& Heap, 1986). The arrest of development is more conspicuous in inbred than in crossbred mice, and the number of embryos that develop normally is greatly reduced unless exogenous progesterone is given within $48 \mathrm{~h}$ of antibody treatment (Rider $e t$ al., 1985). In contrast, a normal number of blastocysts is found in crossbred mice at Day 4 after antibody treatment at $32 \mathrm{~h}$ p.c.

The time of antibody administration (at $32 \mathrm{~h}$ p.c.) coincides with a critical stage in early embryo development in the mouse. Previous studies of cell cycle kinetics have demonstrated that the length of the $G_{2}+M$ phase of the first and second cell cycles is much longer than that of the third (4-cell) or fourth (8-cell). The characteristics of the $3 \mathrm{rd}$ and 4 th cycles are intermediate between those of the maternally regulated first and second cell cycles and those of differentiated cells (Sawicki et al., 1978; Smith \& Johnson, 1986). Values for the $G_{2}+M$ phase of the first and second cell cycles differ between various stocks (Molls et al., 1983), suggesting that the contrasting responses seen in the present study may be related to the relative duration of certain phases during the first two cell cycles. However, when antibody was given at $8 \mathrm{~h}$ p.c. it blocked the establishment of pregnancy in $F_{1}$ hybrid females, but the effect involved suppression of endometrial sensitivity rather than retardation of cleavage. These results show that an earlier exposure to antibody is required in $F_{1}$ hybrid than in inbred stocks in order to disrupt the hormonal sequence which predisposes the endometrium to blastocyst implantation (Finn \& Martin, 1967), and that cleavage is relatively insensitive to the effects of passive immunization in $\mathrm{F}_{1}$ hybrid females. Antibody treatment on the morning after mating was therefore necessary to achieve an antifertility effect in $\mathrm{F}_{1}$ hybrid mice.

In conclusion, the findings of the present study show that passive immunization against progesterone blocks pregnancy by an arrest of early embryo development through an indirect mechanism, and by a decrease in endometrial sensitivity to a deciduogenic stimulus, but that both these effects are modified by genotype by mechanisms that remain to be elucidated.

We thank Mrs R. Butchart, Mrs E. Tredgett and Mr A. Woodley for skilled technical assistance; Mr D. E. Walters for statistical analysis; the World Health Organization, Geneva (M.-Y.W.); and Johnson and Johnson, New Brunswick, U.S.A. for financial assistance; and Mrs J. Tickner for typing the manuscript for publication. V.R. thanks the Lalor Foundation for a Research Fellowship.

\section{References}

Babinet, C., Kemler, R., Dubois, P. \& Jacob, F. (1977) Monovalent fragments of rabbit anti-F9 immunoglobulins prevent the formation of blastocyst in the mouse. C. r. hebd. Séanc. Acad. Sci., Paris D 284, 1919-1922.
Brinster, R.L. (1965) Studies on the development of mouse embryos in vitro. II. The effect of energy source. J. exp. Zool. 158, 59-68.

Brinster, R.L. (1970) In vitro cultivation of mammalian ova. Adv. Biosci. 4, 199-233. 
Bronson, F.H., Dagg, C.P. \& Snell, G.B. (1966) Reproduction. In Biology of the Laboratory Mouse, 2nd edn, pp. 187-204. Ed. E. L. Green. McGraw Hill, New York.

Cox, D.R. (1970) The Analysis of Binary Data. Methuen, London.

Finn, C.A. \& Martin, L. (1967) Patterns of cell division in the mouse uterus during early pregnancy. $J$. Endocr. 39, 593-597.

Goldbard, S.B. \& Warner, C.M. (1982) Genes affect the timing of early mouse embryo development. Biol. Reprod. 27, 419-424.

Goldbard, S.B., Verbanac, K.M. \& Warner, C.M. (1982) Role of the H-2 complex in preimplantation mouse embryo development. Biol. Reprod. 26, 591-596.

Heap, R.B., Rider, V. \& Feinstein, A. (1984) Monoclonal progesterone antibodies and early embryo development. Proc. I0th Int. Cong. Anim. Reprod. \& A.I., Urbana-Champaign, VIII, 14-21.

McLaren, A. \& Bowman, P. (1973) Genetic effects on the timing of early embryo development in the mouse. $J$. Embryol. exp. Morph. 30, 491- 498.

Molls, M., Zamboglou, N. \& Streffer, N. (1983) A comparison of cell kinetics of pre-implantation mouse embryos from two different mouse strains. Cell Tissue Kinet. 16, 277-283.

Nieder, G.L. \& Corder, C.N. (1982) Quantitative and histochemical measurement of pyruvate and lactate in mouse oviduct during the estrous cycle. J. Histochem. Cytochem. 30, 1051-1058.

Niwa, K., Araki, M. \& Iritani, A. (1980) Fertilization in vitro of eggs and first cleavage of embryos in different strains of mice. Biol. Reprod. 22, 1155-1159.

Oliphant, G., Cabot, C., Ross P. \& Marta, J. (1984a) Control of humoral immune system within the rabbit oviduct. Biol. Reprod. 31, 205-212.

Oliphant, G., Reynolds, A.B., Smith, P.F., Ross, P.R. \& Marta, J.S. (1984b) Immunocytochemical localization and determination of hormone-induced synthesis of the sulfated oviductal glycoproteins. Biol. Reprod. 31, 165-174.

Rider, V. \& Heap, R.B. (1986) Heterologous antiprogesterone monoclonal antibody arrests early embryonic development and implantation in the ferret (Mustela putorius). J. Reprod. Fert. 76, $459-470$.

Rider, V., McRae, A., Heap, R.B. \& Feinstein, A. (1985) Passive immunization against progesterone inhibits endometrial sensitization in pseudopregnant mice and has antifertility effects in pregnant mice which are reversible by steroid treatment. J. Endocr. 104, 153-158.

Rider, V., Wang, M.-Y., Finn, C., Heap, R.B. \& Feinstein, A. (1986) Antifertility effect of passive immunization against progesterone is influenced by genotype. $J$. Endocr. 108, 117-121.

Sawicki, W., Abramezuk, J. \& Blaton, O. (1978) DNA synthesis in the second and third cell cycles of mouse preimplantation development. Expl Cell Res. 112, 199-205.

Scatchard G. (1949) The attraction of proteins for small molecules and ions. Ann. N.Y. Acad. Sci. 51, $660-672$

Shire, J.G.M. \& Whitten, W.K. (1980a) Genetic variation in the timing of first cleavage in mice: effect of paternal genotype. Biol. Reprod. 23, 363-368.

Shire, J.G.M. \& Whitten, W.K. (1980b) Genetic variation in the timing of first cleavage in mice: effect of maternal genotype. Biol. Reprod. 23, 369-376.

Smith, R.K.W. \& Johnson, M.H. (1986) Analysis of the third and fourth cell cycles of mouse early development. J. Reprod. Fert. 76, 393-399.

Stone, S.L., Richardson, L.L., Hamner, C.E. \& Oliphant, G. (1977) Partial characterization of hormonemediated inhibition of embryo development in rabbit oviduct fluid. Biol. Reprod. 16,647-653.

Tarkowski, A.K. (1966) An air drying method for chromosome preparations from mouse eggs. Cytogenetics 5 , 394. 400 .

Walters, D.E. (1986) On the reliability of Bayesian confidence limits for a difference of two proportions. Biometrical J. 28, 337-346.

Wang, M.-Y., Rider, V., Heap, R.B. \& Feinstein, A. (1984) Action of anti-progesterone monoclonal antibody in blocking pregnancy after postcoital administration in mice. $J$. Endocr. 101, 95-100.

Warner, C.M., Gollnick, S.O. \& Goldbard, S.B. (1984) Genetic-control of early embryonic development by gene(s) in the MHC (H-2 complex). Proc. 10th Int. Cong. Anim. Reprod \& A.I., Urbana-Champaign, XIII, 10- 15 .

Wright, L.J., Feinstein, A., Heap, R.B., Saunders, J.C., Bennett, R.C. \& Wang, M.-Y. (1982) Progesterone monoclonal antibody blocks pregnancy in mice. Nature, Lond. 295, 415-417. 